\title{
MEMBANGUN MANAJEMEN MUTU DENGAN PRINSIP SIX SIGMA PADA LEMBAGA PENDIDIKAN ISLAM DI ERA GLOBAL
}

\author{
Dalmeri ${ }^{*}$, Supadi $\left.{ }^{*}\right)$ \\ *) Universitas Indraprasta PGRI Jakarta \\ dalmeri300@gmail.com \\ * Universitas Indraprasta PGRI Jakarta \\ supadi5565@gmail.com
}

\begin{abstract}
ABSTRAK
Perguruan tinggi agama Islam (PTAI) sebagai bagian integral dari sistem pendidikan nasional tidak bisa melepaskan diri dari perubahan paradigma baru perguruan tinggi yang saat ini sedang gencar terjadi. Ada paradigma baru ini, kebijakan pengelolaan perguruan tinggi harus lebih terbuka, transparan, dan akuntabel. Saat ini PTAI menghadapi dua permasalahan serius, yakni kualitas lulusan yang dihasilkan dan sumbangan PTAI pada pengembangan ilmu keislaman. Pada konteks kualitas lulusan, kapasitas intelektual dan keilmuan para lulusan PTAI menunjukkan bahwa banyak dari para lulusan PTAI yang belum sanggup menjawab setiap permasalahan keagamaan yang berkembang di tengah-tengah masyarakat. Masalah kedua di atas disebabkan karena geliat yang ada di dalam kampus saat ini lebih banyak yang bersifat politis daripada ilmiah. Selain itu, tradisi menulis karya ilmiah atau penelitian di kalangan kampus PTAI juga terkesan dipaksakan. Tulisan ini berupaya menwarkan gagasan untuk membangun Managemen Penjaminan Mutu dengan Prinsip Six Sgima pada Perguruan Tinggi Agama Islam (PTAI) untuk Merespon Tantangan Nasional dan Global. Mengacu pada semangat paradigma baru Perguruan Tinggi dan problem yang dihadapi oleh PTAI ini, maka keberadaan jaminan mutu (quality assurance) di PTAI penting dilakukan. Selama ini, mayoritas PTAI tidak memiliki lembaga atau unit penjaminan mutu karena dua alasan. Pertama, khusus bagi PTAIN sebagai lembaga yang selalu disubsidi pemerintah, selama ini merupakan "anak manja” yang keberadaannya terjamin APBN, bagaimanapun kualitasnya. Kedua, sebagai akibat dari alasan pertama, pada umumnya pimpinan PTAI melihat proses penjaminan mutu sebagai tugas manajemen dirinya.
\end{abstract}

Kata Kunci: Six Sigma, Manajemen Mutu, Penjaminan Mutu, Total Quality 


\section{A. PENDAHULUAN}

Ada suatu perspektif perkembangan nasional dan global, pengembangan paradigma baru bagi Perguruan Tinggi di Indonesia merupakan suatu keniscayaan. Barangkali hal ini terungkap dalam "World Declaration on Higher Education for the Twenty-First Century,'(UNESCO, I998: I) dalam dunia yang tengah berubah sangat cepat, terdapat kebutuhan mendesak bagi adanya visi dan paradigma baru. Paradigma baru itu, mau tidak mau, melibatkan reformasi besar yang mencakup perubahan kebijakan yang lebih terbuka, transparan, dan akuntabel. Dengan reformasi dan perubahan, diharapkan kepercayaan publik terhadap Perguruan Tinggi meningkat serta dapat memenuhi tuntutan masyarakat yang selalu berkembang (Kodrat, 2018: 3).

Perguruan Tinggi Agama Islam (PTAI) sebagai bagian integral dari sistem pendidikan nasional juga tidak bisa melepaskan diri dari kondisi real di atas (Azra, 2015: 86). Persoalan ini disebabkan, di PTAI juga terdapat dana publik yang ditarik dari masyarakat melalui sumbangan penyelenggaraan pendidikan (SPP) dan yang dialirkan dari APBN. Dengan melakukan perubahan kebijakan yang lebih terbuka, transparan, dan akuntabel akan menunjukkan komitmen PTAI dalam menjaga amanat para orang tua dan pemerintah. Bila tidak, maka PTAI akan digilas oleh zaman dan semakin ditinggal oleh masyarakat. Adapun dasar pemikiran yang bisa dipakai saat ini bisa dinyatakan bahwa PTAI menghadapi dua permasalahan serius, yakni: (I) kualitas lulusan yang dihasilkan dan (2) sumbangan PTAI pada pengembangan ilmu agama Islam. Terkait dengan kualitas lulusan, kapasitas intelektual dan keilmuan para lulusan PTAI menunjukkan bahwa banyak dari para lulusan PTAI yang belum sanggup menjawab setiap permasalahan keagamaan yang berkembang di tengah-tengah masyarakat.

Berkaitan dengan minimnya sumbangan PTAI pada pengembangan ilmu-ilmu Islam. Karena itu penulis menyarankan perlunya pencarian yang ideal tentang studi Islam di kalangan PTAI, terutama untuk mewujudkan cita-cita pendidikan Islam yang adiluhung. Orientasi studi keislaman yang dilakukan oleh PTAI di Indonesia saat ini juga masih belum begitu jelas, terutama dalam menentukan pola, arah, dan capaian tertentu yang diinginkan. Persoalan mendasar yang menjadi kegelisahan setiap akademisi adalah bagaimana membangun manajemen mutu dengan prinsip six sigma di lembaga pendidikan Islam pada era global. Penelitian ini berupaya untuk menawarkan gagasan tentang membangun manajemen mutu dengan prinsip six sigma pada lembaga pendidikan Islam dalam menjawab tantangan globalisasi yang semakin kompleks dengan persaingan terbuka, dan sangat kompetitif dengan mengunakan pendekatan manajemen mutu dalam pengelolaan lembaga pendidikan Islam.

\section{B. PERMASALAHAN YANG DIHADAPI OLEH LEMBAGA PENDIDIKAN IS- LAM}

Minimnya kajian dan kualitas keilmuan di kalangan PTAI membuat prihatin banyak kalangan. Satu di antaranya, Penulis mengidentifikasi bahwa dalam lima tahun belakangan memang belum ada perubahan yang impresif terhadap peningkatan kualitas keilmuan di kalangan PTAI (Asikin, 2018: 
3I8). Bahkan, kalaupun ada geliat di dalam kampus, hal tersebut lebih banyak yang bersifat politis daripada ilmiah. Barangkali penulis sangat menyayangkan tradisi menulis karya ilmiah atau penelitian di kalangan kampus PTAI yang terkesan dipaksakan. Penulisannya hanya dilakukan sebagai syarat demi kepentingan naik pangkat.

Kedua permasalahan yang dihadapi PTAI di atas, menurut penulis disebabkan oleh beberapa hal. Pertama, lemahnya kemampuan para mahasiswa PTAI memahami ilmu-ilmu keislaman secara tahqiq. Hal ini disebabkan karena sebelum mereka masuk PTAI, mayoritas dari mereka yang diterima di PTAI tidak memiliki kemampuan dasar materi-materi keislaman. Misalnya tidak mampu membaca alQur'an dengan tartil, menguasai bahasa Arab, dan memahami dasar-dasar pendekatan ilmuilmu keislaman.

Kedua, PTAI kurang memiliki komitmen baik dalam menjaring calon mahasiswa maupun menjaring calon dosen. Sebagai contoh sederhana, dalam penjaringan mahasiswa baru di PTAI Negeri maupun Swasta di Kawasan Jakarta selama tiga tahun terakhir dapat dilihat betapa longgarnya proses penjaringan mahasiswa baru. Kondisi ini tentu tidak berbeda jauh dengan PTAI lainnya di luar Jakarta yang ada di Indonesia. Akibatnya, calon mahasiswa yang diterima tidak memiliki dasar materi keislaman yang diharapkan (Elbadiansyah, 2017: 48).

Hasan Asari melihat kelemahan lain pada PTAI yakni masalah anggaran yang dialokasikan ke Kementerian Agama jauh lebih kecil dibandingkan dengan Departemen Pendidikan Nasional. Sebagai akibat dari kondisi ini adalah dana operasional IAIN sangat terbatas (Asari, 1994: 45). Sedangkan faktor lain yang mempengaruhi juga diungkap oleh Shahrin:

"...now the most crucial thing to be done is a comprehensive internal reorganization in IAIN. IAIN has not undertaken serious reconstruction to all its internal institutions. So far, IAIN still has many weaknesses even in basic matters; many activities do not have proper manuals, weak discipline among teaching and administrative staff, and so on .... Another problem is recruitment of teaching staff" (Harahap, I998: 26).

Terkait dengan penilaian dan kelemahan terhadap PTAI ini, Qodry A. Azizy berpendapat bahwa pihak PTAI tidak perlu berkecil hati. Hal ini disebabkan karena penilaian ini bukan untuk menjelek-jelekkan PTAI, akan tetapi dalam rangka instropeksi diri guna lebih baik dalam melaksanakan program selanjutnya (Azizy, 2003: 26). Karena itu, PTAI harus mampu menciptakan, memperoleh, dan mentransfer pengetahuan dengan cara melakukan klarifikasi tujuan, kelengkapan fasilitas penunjang, proses kerja yang efisien dan evaluasi yang efektif (A. Qodry Azizy, 2005: 83).

Mengacu pada semangat paradigma baru Perguruan Tinggi dan problem yang dihadapi oleh PTAI di atas, maka PTAI perlu dikelola sebagai sebuah lembaga yang sehat dan menggunakan sistem berdasarkan merit, transparansi, dan akuntabilitas publik. Sebuah lembaga pendidikan tinggi dikatakan sehat apabila memenuhi beberapa kriteria sebagaimana berikut. (I) proses pembelajaran yang efektif, (2) pendidikan tepat waktu, (3) staf dan mahasiswa disiplin, (4) ada relevansi antara pengajaran dan penelitian, (5) lulusan banyak 
diterima di masyarakat, dan (6) efisien dalam penggunaan sumber daya dan dana (A. Qodri Azizy, 2007: 46). Sementara itu, pada bagian lain Kementerian Riset dan DIKTI melontarkan isu strategis berupa RAISE atau Relevance, Academic Atmosphere, Internal Management and Organization, Sustainability, Efficiency dan Productivity untuk menjaga keberlangsungan dan pengembangan institusi pendidikan tinggi dan ini juga dapat dijadikan rujukan untuk pengembangan PTAI (A. Qodry Azizy, 2005: 98).

\section{Relevance (relevansi) merupakan} cerminan dari tingkat sensitivitas institusi PTAI terhadap lingkungan di mana PTAI tersebut berada. Tingkat sensitivitas ini dapat dilihat dari berbagai aktivitas yang dilakukan oleh PTAI tersebut dalam memberikan respon pada lingkungannya dan sangat bergantung pada disiplin atau bidang keilmuan, bentuk-bentuk keterkaitan dan kapasitas yang dimiliki oleh institusi tersebut. Untuk IAIN, relevansi ditinjau dari 2 (dua) sisi yaitu (I) sisi mutu lulusan dan (2) keterserapan lulusan pada segmen dunia kerja.

Academic atmosphere (suasana akademik) yang kondusif merupakan persyaratan yang mutlak untuk terjadinya suatu interaksi yang sehat antara dosen dan mahasiswa, antar sesama dosen, dan antar sesama mahasiswa. Suasana akademik yang sehat akan menjamin terjadinya kepuasan dan memacu motivasi serta kreativitas di kalangan sivitas akademika dalam menjalankan kegiatan akademik yang pada gilirannya akan menghasilkan produk akademik yang berkualitas. Suasana akademik yang kondusif ditandai dengan terjadinya interaksi yang optimal antara dosen dan mahasiswa baik di dalam maupun di luar ruang kuliah, para dosen seyogyanya merupakan model panutan untuk penegakan nilai-nilai dan norma akademik, kebebasan mimbar, dan sistem pengambilan keputusan yang didasarkan pada azas pemilihan yang terbaik (merit sistem), adil dan transparan. Internal management and organization (manajemen internal dan organisasi). Komitmen untuk meningkatkan sistem manajemen dan organisasi yang mengarah pada suatu penyelenggaraan program pendidikan yang efektif dan efisien merupakan salah satu aspek yang berkaitan dengan upaya peningkatan kualitas penyelenggaraan program pendidikan. Termasuk di antaranya adalah upaya peningkatan kinerja dan motivasi di kalangan staf, pembenahan sistem perencanaan dan penganggaran yang mencerminkan prioritas, pengembangan sistem dan pengawasan internal serta evaluasi, sistem prosedur dan pengambilan keputusan yang efisien, serta kiat-kiat yang menjamin terjadinya pengelolaan institusi yang transparan dan pemanfaatan sumber daya yang efisien dan efektif.

Sustainability (keberlanjutan), pada dasarnya terdiri dari 3 (tiga) hal yang perlu mendapatkan perhatian, yaitu (I) aspek keberlanjutan yang menjamin eksistensi institusi, (2) aspek keberlanjutan yang menjamin tingkat kualitas yang telah dicapai melalui program pengembangan dan (3) aspek keberlanjutan atas sumber daya yang telah diadakan (invested resources). Aspek eksistensi institusi diperlihatkan dari dana operasional yang berhasil didapatkan dari berbagai sumber, seperti dari masyarakat, pemerintah, dan stakeholder. Aspek tingkat kualitas, diperlihatkan dari seberapa banyak praktek-praktek baik yang diadopsi untuk dilaksanakan pada pelaksanaan kegiatan 
yang bersifat rutin dan berkesinambungan. Aspek sumber daya yang diadakan, diperlihatkan dari usaha yang dilakukan oleh institusi tersebut dalam memelihara dan mempertahankan sumber daya.

Memperhatikan uraian di atas, keberadaan jaminan mutu (quality assurance) di Perguruan Tinggi Agama Islam (PTAI) penting dilakukan. Lembaga atau unit ini perlu mendapatkan tugas untuk:(I)menentukankualitas yang harus dicapai dalam segala hal, (2) menentukan prosedur kerja untuk mencapai kualitas itu, (3) melakukan uji standar mutu ke PT dalam dan luar negeri, dan (4) berperan sebagai mitra dalam memberikan saran perbaikan mutu bagi pimpinan PTAI dari hulu sampai hilir. Oleh karena itu, tulisan ini mencoba mengkaji kegiatan penjaminan mutu yang sudah dilakukan oleh beberapa perguruan tinggi umum (PTU) di Indonesia dan juga memaparkan pengalaman IAIN Sunan Ampel Surabaya dalam menerapkan penjaminan mutu selama satu tahun lebih (Mochtar, 200I: 76). Dengan demikian penjelasan ini dimaksudkan sebagai bahan benchmark bagi PTAI dan mengkritisi praktek-praktek yang sudah berjalan selama ini. Selain itu, diharapkan dapat menjadi inspirasi bagi pengelola PTAI untuk selalu meningkatkan mutu akademik melalui kegiatan penjaminan mutu

\section{MENGANALISIS PERMASALAHAN YANG DIHADAPI OLEH LEMBAGA PENDIDIKAN ISLAM DENGAN PRIN- SIP SIX SIGMA UNTUK MANAJEMEN MUTU}

\section{Pengertian Six Sigma}

Pembahasan mengenai pengertian Six Sigma, tidak dapat hanya merumuskan Six
Mengingat Six Sigma mempunyai banyak pengertian ditinjau dari berbagai konteks. Bahkan setiap perusahaan mempunyai definisi tersendiri mengenai Six Sigma ini. Dari sekian banyak pengertian-pengertian yang ada, penulis berusaha untuk mengolah dan menyajikan beberapa pengertian Six Sigma yang paling relevan dengan manajemen mutu dan paling tepat mendefinisikan pengertian Six Sigma ini. Six Sigma dapat diartikan sebagai suatu metode yang digunakan oleh para insinyur dan statistikawan dalam memperbaiki atau mengembangkan proses atau produk. Six Sigma dapat diartikan demikian karena kunci utama perbaikan Six Sigma adalah menggunakan metode-metode statistic (Pande \& Holpp, 2005: 4).

Secara sederhana Six Sigma pada beberapa organisasi dapat diartikan sebagai suatu ukuran kualitas yang bergerak ke arah kesempurnaan (Evans \& Lindsay, 2007: 7). Maksudnya adalah Six Sigma merupakan suatu disiplin, pendekatan melalui data dan suatu metodologi untuk mengurangi atau meniadakan kesalahan (defects) dalam produksi dalam semua proses, mulai dari proses manufaktur hingga transaksi dan dari produk ke pelayanan (service) (Pyzdek \& Keller, 2018: 8).

Sigma, merupakan simbol standard deviasi pada statistik, suatu ukuran untuk menyatakan variance atau variasi, atau ketidaktepatan sekelompok item atau proses (Brue, 2005: II). Tujuan dari Six Sigma adalah untuk mengurangi variasi pada output sehingga tidak akan melampaui enam standard deviasi (Six Sigma) antara rata-rata (mean) dan batas spesifikasi terdekat (George, Blackwell, \& Rajan, 2019: 28). Proses-proses Six Sigma harus dapat 
menghasilkan kesalahan kurang dari 3,4 per juta peluang (per million opportunities). Dengan demikian, apabila tercapai, maka Six Sigma akan dapat memastikan bahwa keseluruhan proses produksi berjalan pada efisiensi yang optimal (P. S. Pande, Neuman, \& Cavanagh, 20I4: 26).

Six Sigma adalah suatu pendekatan ke arah kostumer atau pelanggan (customer base approach) yang menyadari bahwa kesalahan produksi merupakan biaya yang mahal (McMunigal \& Barry Bebb, 20I5: I2). Tingkat kesalahan yang rendah mengakibatkan penurunan dari segi biaya dan meningkatkan loyalty atau kesetiaan pelanggan (Gupta, 2015: 34). Produsen dengan biaya yang terendah dan penilaian yang tinggi dari pelanggan merupakan produsen yang paling kompetitif dalam penyediaan produk dan jasa (Dlugacz, 2004: 2). Maka dari itu, dapat dipahami bahwa six sigma merupakan suatu alat untuk mencapai strategi bisnis ini.

Dari sekian banyak pengertian di atas, maka dapat disederhanakan menjadi satu definisi yang lengkap danjelas, yaitu: Six Sigma merupakan suatu sistem yang komprehensif dan fleksibel untuk mencapai, memberi dukungan dan memaksimalkan proses usaha, yang berfokus pada pemahaman akan kebutuhan pelanggan dengan menggunakan fakta, data, dan analisis statistik serta terus menerus memperhatikan pengaturan, perbaikan dan mengkaji ulang proses usaha.

Keuntungan dari penerapan Six Sigma berbeda untuk setiap perusahaan, tergantung pada usaha yang dijalankannya, visi dan misi serta strategi perusahaan bersangkutan (Geneen, 20I2: 2I2). Tetapi umumnya dengan penerapan six sigma akan ada perbaikan dalam hal-hal berikut ini:

a. Pengurangan biaya

b. Perbaikan produktivitas

c. Pertumbuhan pangsa pasar

d. Pengurangan waktu siklus

e. Retensi pelanggan atau loyalitas pelanggan

f. Pengurangan kesalahan pada produk atau produk cacat

g. Perubahan budaya kerja Pengembangan produk atau jasa (Kerzner, 2018: 228).

Six Sigma mempunyai kesamaan dengan prinsip-prinsip dan alat-alat kualitas yang dikembangkan oleh W. Edwards Deming dan Joseph Juran. Hal-hal yang terselubung di balik penerapan Six Sigma adalah sebagai berikut:

I) Six Sigma meliputi sekumpulan praktik dan ketrampilan usaha yang merupakan kunci menuju kesuksesan dan perkembangan ke arah yang lebih baik. Six Sigma dapat diterapkan di bidang usaha apa saja mulai dari perencanaan strategi sampai operasional hingga pelayanan kepada pelanggan.

2) Ada banyak pendekatan Six Sigma, karena setiap perusahaan akan mempunyai pendekatan yang berbeda dengan perusahaan lainnya, sesuai dengan budaya kerja serta visi misi perusahaan tersebut. Keuntungan Six Sigma akan terlihat kita memimpin keseluruhan organisasi atau departemen dalam perusahaan kita.

Six Sigma sangat berpotensi diterapkan pada bidang jasa atau non-manufakturing di samping lingkungan yang bersifat teknikal. Misalnya pada bidang manajemen, keuangan, pelayanan pelanggan, pemasaran, logistik, teknologi informasi, dan sebagainya (Tompkins, 2005: 37). Permasalahan ini dikarenakan hal- 
hal berikut:

a) Aktivitas-aktivitas ini merupakan kunci yang mendukung keberhasilan kompetitif suatu perusahaan, seperti produk yang terukur berubah menjadi komoditi dalam pemesanan jangka pendek.

Ada banyak kelebihan lainnya, karena biasanya aktivitas non-manufaktur hanya mempunyai efektivitas sebesar 70\% (Davis \& Fifolt, 2018: 84).

Jadi, Six Sigma dimaksudkan untuk berperan dalam bidang komersial transaksi dan administrasi yang memerlukan pendekatan khusus.

3) Six Sigma sebagai keberhasilan individu dan keberhasilan teknikal. Kreativitas, kolaborasi, komunikasi, dan dedikasi merupakan halhal yang lebih mempengaruhi keberhasilan perusahaan. Ide-ide pokok Six Sigma dapat memberi inspirasi dan memotivasi ide-ide dan kinerja yang lebih baik dari karyawankaryawan, dan menciptakan strategi yang mendayagunakan kemampuan pribadi karyawan dan kemampuan teknikal.

Six Sigma bila ditinjau dari segi perolehan finansial akan terlibat pada keuntungan intangible (tak terukur). Perubahan sikap dan budaya kerja perusahaan yang diperoleh dari perbaikan proses dan karyawan-karyawan yang telah diberi pelatihan mengenai Six Sigma akan memberi keuntungan kepada perusahaan bukan berupa uang, tetapi berupa hal lain yang lebih berharga (S. K. Gupta, Antony, Lacher, \& Douglas, 2018: 508).

2. Prinsip Manajemen Six Sigma

Manajemen Six Sigma dalam jangka panjang akan bersatu dalam suatu sistem looptertutup yang memerlukan feedback atau umpan balik berupa sekumpulan informasi internal dan eksternal yang akan menginformasikan kepada para manajer bagaimana kinerja perusahaan harus dipertahankan dan bagaimana perusahaan dibawa ke arah pertumbuhan yang lebih baik (Cudney, Venuthurumilli, Materla, \& Antony, 2018: 8).

Sistem loop-tertutup yang baik akan bertahan walaupun perusahaan harus menghadapi masalah dan ketidakpastian yang melanda perusahaan di dalam atmosfir bisnis yang serba tidak menentu ini (Dlugacz, 2004: 2). Karena itu, penerapan Six Sigma dengan sistem loop-tertutup ini akandapat mengurangi arah yang tidak menentu pada perusahaan dan tetap menjaga kestabilan kinerja serta keberhasilan perusahaan.

Pada perusahaan, stimuli internal adalah pengukuran aktivitas bagian dalam proses, sedangkan elemen feedback eksternal adalah hal-hal apa saja yang diinformasikan kepada perusahaan mengenai keberhasilannya mencapai tujuan atau tetap berada di jalur yang tepat, termasuk keuntungan yang berhasil diperolehnya, serta kepuasan pelanggan dan berbagai sumber data lainnya.

Sebenarnya dalam Six Sigma, ketidakpastian atau arah yang tak menentu ini disebut variasi. Variasi buruk yang berpengaruh negatif pada pelanggan disebut cacat (Laureani \& Antony, 2018: 528). Pendekatan yang digunakan untuk membuat, memonitor, dan memperbaiki sistem bisnis loop tertutup disebut manajemen proses, perbaikan proses, dan desain ulang proses untuk bias berjlan dengan baik sesuai dengan gambar berikut: 


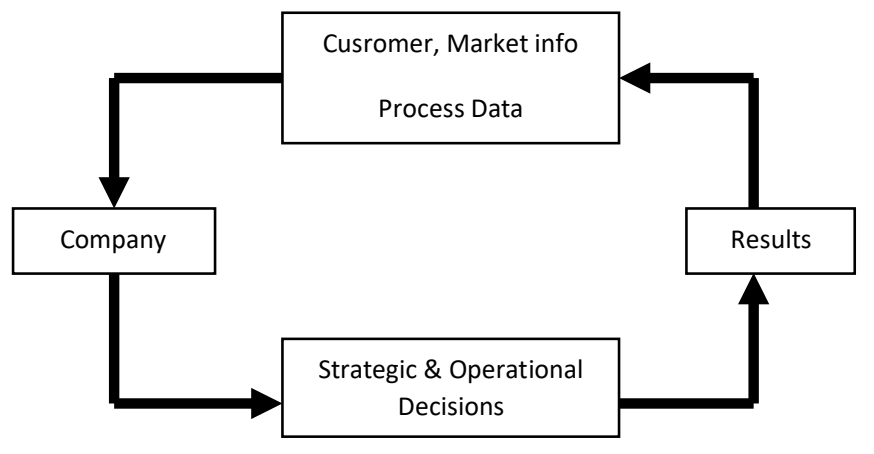

Gambar I. Sistem Loop Tertutup

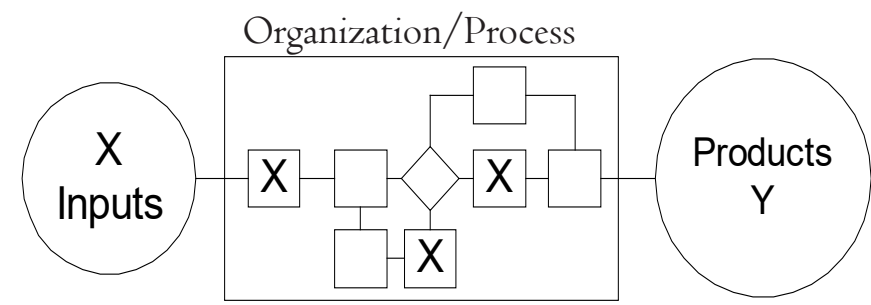

Gambar 2. Model Proses Bisnis

Gambar tersebut di atas menunjukkan pada sebelah kiri adalah input dari proses atau sistem. Tengah adalah organisasi atau proses, melukiskan peta proses atau bagan arus. Sebelah kanan adalah produk hasil output dari sistem atau proses, serta akan meliputi pelanggan penting dan juga keuntungan yang akan diraih (Evans \& Lindsay, 2007: 29).

Ada penambahan sedikit kata-kata berupa huruf $\mathrm{X}$ dan $\mathrm{Y}$ pada gambar di atas yang mewakili pengukuran atau variabel pada bagian-bagian yang berbeda di dalam sistem. "X" menunjukkan masukan dan aliran proses sebagai petunjuk perubahan pada bagian upstream dari sistem. Sedangkan "Y" menunjukkan pengukuran kinerja usaha (Evans \& Lindsay, 2007: 38).

Rumus $\mathrm{Y}=\mathrm{f}(\mathrm{x})$ yang dapat dibaca $\mathrm{Y}$ adalah fungsi dari $x$, adalah cara matematis untuk menyatakan perubahan atau variabel di dalam masukan dan proses sistem akan sangat menentukan skor akhir atau Y. Y bisa berarti tujuan strategi, kebutuhan pelanggan, keuntungan, kepuasan pelanggan, serta efisiensi bisnis secara keseluruhan. Sedangkan X bisa berarti tindakan penting untuk mencapai tujuan strategi, kualitas hasil kerja, pengaruh inti pada kepuasan pelanggan, variabel-variabel proses seperti waktu siklus, teknologi, sumber daya dan lain-lain, serta kualitas masukan pada proses dari pelanggan maupun supplier (Evans \& Lindsay, 2007: 4I).

Selama ini banyak perusahaan yang belum dapat memahami hubungan antara variabel $\mathrm{X}$ da $\mathrm{Y}$. Tetapi dengan Six Sigma, perusahaan akan dapat memahami sistem dan variabel mana yang dapat dimonitor dan direspon balik dengan cepat, serta dapat secara otomatis mengenali tandatanda prosesnya, pemasoknya, karyawannya terutama pelanggan dan pesaing, sehingga akan dapat mencapai kekuatan dan kinerja yang baru serta efektif (Evans \& Lindsay, 2007: 48).

Keuntungan penerapan Six Sigma ditinjau dari segi manajemen, antara lain adalah:

I) Six Sigma mengukur permintaan dalam arti yang sebenarnya dari apa yang dibutuhkan pelanggan. Hal ini akan menguntungkan kedua belah pihak dalam memikirkan apa saja yang benar-benar signifikan dalam proses bisnis ini.

2) Menyediakan pengukuran yang sifatnya konsisten. Dengan berfokus pada cacat atau kemungkinan terjadinya cacat, pengukuran Six Sigma dapat digunakan untuk mengukur dan membandingkan proses-proses yang berbeda di dalam organisasi. Begitu kebutuhan dapat didefinisikan secara jelas, maka akan dapat didefinisikan cacat dan mengukur hampir semua aktivitas dan proses usaha.

Menyatukan tujuan yang penuh ambisi dengan memusatkan perhatian seluruh organisasi pada tujuan kinerja 99,997\%. Maka perbaikan yang cukup signifikan dalam perusahaan akan dapat tercapai (Pyzdek \& Keller, 2018: 86).

Adapun beberapa hal logis seputar penerapan Six Sigma adalah: 
I) Agar penerapan Six Sigma efektif, diperlukan pedoman-pedoman yang jelas. Hal ini untuk mencegah jalan perusahaan menuju ke arah yang tidak konsisten dan berpotensi untuk menjadi tidak seimbang, yaitu di mana terdapat dua kelompok yang saling membandingkan asumsi yang berbeda-beda.

2) Sifat Six Sigma adalah tidak statis (dinamis). Maksudnya adalah Six Sigma selalu berubah mengikuti keadaan dan kondisi perusahaan. Misalnya apabila kebutuhan pelanggan berubah, maka kinerja Six Sigma juga akan berubah untuk mengakomodasi perubahan tersebut.

Seperti halnya pengukuran yang lain, Six Sigma juga membutuhkan waktu dan sumber daya. Manajemen harus dapat membuat prioritas apa yang harus diukur terlebih dahulu (Brue, 2005: 27).

Dengan demikian, implementasi penjaminan mutu melalui prinsip Six Sigma ini sangat mudah dan efekti untuk dilaksanakan serta pola penerapannya bisa dilakukan secara fleksibel atau dinamis sesuai dengan keperluan menurut target yang akan dicapai dan tidak kaku atau statis karena prinsip ini dilaksanakan dengan skala prioritas dan terukur.

\section{A. STRATEGI MANAJEMEN DAN PER- BAIKAN SIX SIGMA DALAM MENG- HADAPI PERMASALAHAN LEMBAGA PENDIDIKAN ISLAM}

Sistem Six Sigma akan berhasil dengan baik apabila terdapat pengetahuan akan kebutuhan pelanggan dan pengukuran yang efektif (Syamsuddin, Samrin, \& Alim, 2018: 22). Sistem Six Sigma digerakan atas dasar tiga strategi dasar, dan semua strategi tersebut berfokus kembali pada proses organisasi perusahaan tersebut. Berikut ini akan diuraikan secara ringkas mengenai tiga $\mathscr{A l} l$-Fikri| Jurnal Studi dan Penelitian Pendidikan Islam Volume 2 Nomor 1 Februari 2019 strategi Six Sigma, yaitu:

I. Perbaikan Proses (Process Improvement): Menemukan solusi untuk mencapai target. Meliputi strategi untuk mengembangkan solusi yang menghilangkan akar penyebab masalah pada kinerja usaha. Disebut juga "Continuous Improvement" atau perbaikan yang berkesinambungan, "Incremental Improvement" atau perbaikan tambahan, dan Kaizen, suatu bentuk perbaikan berkesinambungan ala Jepang.

2. Desain atau Desain Ulang Proses (Process Design or Redesign): Membangun bisnis yang lebih baik.

Tujuan dari desain atau desain ulang proses bukan untuk menyesuaikan suatu proses, tetapi cenderung menempatkan suatu proses atau sebagian proses dengan proses yang baru. Juga serng disebut dengan desain Six Sigma, yaitu prinsip-prinsip Six Sigma digunakan untuk membuat produk atau jasa baru yang berhubungan erat dengan kebutuhan pelanggan dan divalidasikan dengan data serta pengujian yang memadai.

3. Manajemen Proses (Process Management): Infrastruktur kepemimpinan Six Sigma.

Strategi ketiga ini merupakan strategi yang paling evolusioner, karena melibatkan perusahaan dari kesalahan dan arah fungsi hingga pemahaman dan pemudahan proses, yang merupakan aliran kerja yang melibatkan nilai pelanggan dan pemegang saham (Asikin, 2018: 324). Pada manajemen proses ini, kebijakan dan metode Six Sigma menjadi bagian yang menyatu dalam menjalankankan usaha, yaitu:

a) Proses dicatat dan diatur secara end-toend dan tanggung jawab dibuat sedemikian rupa untuk menjamin adanya manajemen proses lintas fungsional atau crossfunctional yang kritis. 
b) Kebutuhan pelanggan diartikan secara jelas dan selalu diperbaharui (update) secara teratur.

c) Pengukuran keluaran, aktivitas proses dan masukan yang menyeluruh dan berarti.

d) Manajer dan bawahannya, termasuk orang yang bersangkutan dalam proses tersebut, menggunakan pengukuran dan pemahaman proses untuk menilai kinerja pada saat yang tepat dan mengambil tindakan untuk mengetahui permasalahan dan peluang apa yang muncul.

Perbaikan proses dan desain atau desain ulang proses yang dilaksanakan bersamaan dengan alatalat perbaikan Six Sigma digunakan secara terus menerus untuk meningkatkan kinerja, daya saing dan profitabilitas perusahaan (Montgomery, 2017: 938).

4. Model-Model Perbaikan Proses Six Sigma

a. PDCA atau PDSA

Merupakan metode berdasarkan langkahlangkah yang dikembangkan oleh W. Edwards Deming. PDCA merupakan singkatan dari Plan-Do-Check-Action, sedangkan PDSA adalah Plan-Do-Study-Act. PDCA/PDSA merupakan suatu flowchart untuk mempelajari dan memperbaiki proses.

I) Plan

Merupakan awal dari siklus PDCA/ PDSA. Di sini, manajemen meninjau ulang kinerja sekarang untuk diangkat sebagai permasalahan. Kemudian mengumpulkan data atas pokok permasalahan yang ada dan mengidentifikasi serta menetapkan akar-akar penyebab masalah. Kemudian memberikan solusi-solusi yang mungkin dijalankan dan merencanakan pelaksanaan pengujian atas solusi yang paling berpotensi.

2) Do

Mengeluarkan perubahan atau pengujian menjadi skala kecil. Do berfungsi sebagai pilot atau secara perlahan mengikuti Plan, karena kalau tidak demikian, proses pembelajaran tidak akan berhasil.

3) Check/Study

Melakukan pengukuran atas hasil pengujian untuk melihat apakah hasil yang diinginkan sudah tercapai atau belum. Bila masalah muncul lagi, maka harus dicari hambatan apa yang telah mengacaukan usaha perbaikan ini. 4) Act

Dengan berdasarkan solusi dan evaluasi pengujian, maka solusi yang sudah terbentuk akan diperbaharui dan diperluas agar permanen, dan menyatukan pendekatan baru lainnya bila memungkinkan. Kemudian mengambil perubahan yang terjadi atau diabaikan, atau kembali lagi ke dalam siklus. Siklus PDSA ini sesuai bila diterapkan dalam lingkungan yang stabil. Karena yang dijalankan adalah semua rencana yang diperbaiki secara kontinu dengan mempelajari hasil yang diperoleh bila rencana tersebut dilaksanakan, dan kemudian mengubah rencana tersebut untuk mendapatkan hasil yang lebih optimal. Tetapi PDSA kurang berhasil apabila diterapkan ke dalam sistem yang jauh lebih kompleks seperti di pasar ekonomi. Maka dikembangkan model baru yaitu, model SEA (Select-Experiment-Adapt) (Zuckweiler, 20I I: I4I).

b. SEA

Pada kehidupan nyata, eksperimen terus berjalan dengan mengandalkan kinerja yang dipacu secara aktif melalui perolehan data dari lingkungan sekitar. Melakukan penelitian atas suatu hal, atau mendorongnya berdasarkan observasi terdahulu dan memutuskan tindakan apa yang paling baik. Tindakan yang diambil sebagaitanggapan dari data disebut aturan kinerja. Adaptasi dilakukan dengan menyesuaikan 
kekuatan aturan kinerja yang berdasarkan hasil yang ingin dicapai.

c. SEA vs PDSA vs SEL

I) SEA digunakan bila eksperimen formal yang terkendali sedang berlangsung. Dengan mengikuti strategi mini-max; minimasi perencanaan dan pengendalian pusat ke kemungkinan perluasan maksimum. Memperbolehkan kebebasan bereksperimen maksimum bagi karyawan dan mengubah lingkungan dan proses kerja mereka untuk mencari cara yang lebih baik untuk melakukan sesuatu.

2) Bila proses dipengaruhi feeback positif dari bagian lain, maka gunakan model SEA dan SEL. Menghapus strategi perencanaan jangka panjang dan berusaha memperkuat lingkungan dengan kemampuan maksimum menyesuaikan diri dengan perubahan yang terjadi.

Bila proses berada atau dekat dengan titik ekuilibrium dan tidak dipengaruhi loop feedback positif, maka akan lebih baik menerapkan PDSA. Karena PDSA berdasarkan perencanaan, penggunaan tim resmi, alat-alat pengendalian proses, desain eksperimen, dan sebagainya (Cudney et al., 2018: 8).

\section{d. DMAIC}

Model pendekatan six sigma yang paling umum digunakan sekarang adalah DMAIC (Define mendefinisikan, Measure - mengukur, Analyze - menganalisis, Improve - memperbaiki, Control - mengendalikan). Berikut ini adalah tinjauan strategi perbaikan proses dan desain atau desain ulang proses pada model DMAIC.

\begin{tabular}{|c|c|c|}
\hline & Perbaikan Proses & $\begin{array}{l}\text { Desain/Desain Ulang } \\
\text { Proses }\end{array}$ \\
\hline Define & $\begin{array}{l}\text { - Identifikasi } \\
\text { masalah }\end{array}$ & $\begin{array}{l}\text { - Identifikasi masalah } \\
\text { - Dertentu } \\
\text { perubisi tujuan/ } \\
\text { - Perjelas jangkauan dan } \\
\text { kebutuhan pelangoan }\end{array}$ \\
\hline Measure & $\begin{array}{l}\text { - P e r t e g a s } \\
\text { m a s a } 1 \text { a h / } \\
\text { proses } \\
\text { - Membenarkan } \\
\text { pengetahuan } \\
\text { tujuan } \\
\text { - Ukur langkah- } \\
\text { langkah inti } \\
\text { ataumasukan }\end{array}$ & $\begin{array}{l}\text { - Ukur kinerja kebutuhan } \\
\text { - Kumpulkan data } \\
\text { secukupnya }\end{array}$ \\
\hline Analyze & $\begin{array}{l}\text { - Kembangkan } \\
\text { hipotesis } \\
\text { - Identifikasi } \\
\text { akar penyebab } \\
\text { utama } \\
\text { - V a } 1 \text { i d a s i } \\
\text { hipotesis }\end{array}$ & $\begin{array}{l}\text { - Identifikasi praktek } \\
\text { terbaik } \\
\text { - Nilai desain proses } \\
\square \quad \text { Pertambahan nilai } \\
\text { atau tidak } \\
\square \quad \text { B o t t l e n e ck / } \\
\text { disconnect } \\
\square \quad \text { Alternatif lainnya } \\
\text { - Perjelas kebutuhan }\end{array}$ \\
\hline Improve & $\begin{array}{l}\text { - Kembangkan } \\
\text { ide untuk }\end{array}$ & $\begin{array}{l}\text { - Desain proses baru } \\
\text { Asumsi-asumsi } \\
\text { yang mendukung } \\
\text { Kreativitas } \\
\text { Kebijakan proses } \\
\text { kerja } \\
\text { - Jalankan proses, struktur } \\
\text { dan sistem baru }\end{array}$ \\
\hline Control & $\begin{array}{l}\text { - Buat standar } \\
\text { pengukuran } \\
\text { untuk } \\
\text { memelihara } \\
\text { kinerja kerja } \\
\text { - B e r e s k a n } \\
\text { permasalahan } \\
\text { sesuai dengan } \\
\text { tujuan yang } \\
\text { diinginkan }\end{array}$ & $\begin{array}{l}\text { - Buat pengukuran } \\
\text { dan kaji ulang untuk } \\
\text { memelihara kinerja } \\
\text { - Bereskan permasalahan } \\
\text { sesuai dengan tujuan } \\
\text { yang diinginkan }\end{array}$ \\
\hline
\end{tabular}


Ada tiga kualifikasi dasar yang harus dipenuhi bila akan menggunakan metode DMAIC, yaitu:

I) Ada celah antara kinerja sekarang dengan yang diharapkan. Pertama-tama perlu ditentukan permasalahan apa yang harus dipecahkan, atau kesempatan apa yang akan diraih. Pada kasus desain proses, ada aktivitas baru yang diluncurkan di mana tidak ada proses yang muncul.

2) Penyebab masalah tidak dipahami secara benar. Pihak manajemen mungkin hanya mengerti permasalahan secara teoritis, tetapi tidak mengetahui akar penyebab masalah.

Solusi belum ditetapkan. Bila pihak manajemen telah merencanakan perubahan jangka pendek, masih ada waktu untuk menerapkan Six Sigma (Evans \& Lindsay, 2007: I43).

Jadi, dengan penerapan Six Sigma secara cepat dapat menghemat waktu untuk analisis yang lebih akurat. Bila suatu usaha secara signifikan telah dijalankan untuk menjembatani celah tersebut, penerapan Six Sigma tidak akan berguna.

I. Six Sigma versus Total Quality Management (TQM)

TQM (Total Quality Management) adalah suatu pendekatan terhadap mutu atau kualitas, yaitu produsen berjuang menciptakan suatu lingkungan yang memungkinkan pekerja menghasilkan produk yang sempurna (zero defects)(P. Gupta, 2015:28). Adapun kelemahan TQM dibandingkan dengan Six Sigma, adalah:

a. Kualitas sering merupakan aktivitas sampingan, terpisah dari isu kunci dari strategi usaha dan kinerja.

b. Pada banyak organisasi, kualitas dirasakan bersifat temporer dan apabila pemimpin yang memprakarsainya meninggalkan perusahaan, kualitas kemudian diabaikan. c. Kebingungan terhadap TQM berasal dari kata kuantitas itu sendiri. Kata kualitas mempunyai banyak arti, tergantung dari bagaimana kita memandangnya. Kualitas merupakan suatu departemen yang ada dengan tanggung jawab khusus untuk pengendalian kualitas, di mana disiplin tersebut cenderung lebih berfokus kepada proses stabilisasi daripada memperbaiki proses. Ide keseluruhan dari filosofi kualitas juga membuat konsep secara keseluruhan tampak misterius bagi kebanyakan orang. Pendekatan-pendekatan baru seperti ISO 9000 atau reengineering tidak terintegrasi ke dalam usaha kualitas yang ada.

d. Banyak perusahaan yang membuat kualitas lebih kabur atau tida jelas dengan menetapkan tujuan yang tampak positif tanpa memilki cara untuk memonitor kemajuan pencapaian tujuan tersebut.

e. TQM merupakan aktivitas yang bersifat hanya di dalam departemen-departemen di banyak perusahaan. Masing-masing departemen mempunyai kebijakannya secara sendiri-sendiri, sehingga tidak mencakup keseluruhan organisasi.

TQM mengajarkan incremental atau perkembangan yang sedikit (small improvement), bukan perkembangan secara radikal (radical improvement) sehingga banyak pemimpin korporat tidak sabar setelah munculnya konsep reengineering. Reengineering adalah desain atau desain ulang bisnis yang mirip dengan process redesign, meskipun prakteknya mencakup skala yang lebih besar (S. K. Gupta et al., 2018: 9).

Adapun keunggulan konsep Six Sigma dibandingkan dengan TQM adalah:

a. Organisasi Six Sigma menjadikan pengelolaan proses, perbaikan, dan pengukuran ke dalam tindakan sebagai bagian dari tanggung jawab 
sehari-hari, terutama bagi manajer operasi. Dengan menggunakan sistem insentif, akan membantu memperkuat keyakinan bahwa Six Sigma merupakan bagian dari pekerjaan.

b. Sasaran yang ditentukan untuk dicapai dengan konsep Six Sigma lebih jelas. Sasaran dalam Six Sigma dinyatakan dalam hasil 99,997\% sempurna, dengan tingkat kesalahan 3,4 per juta peluang.

c. Six Sigma merupakan suatu cara untuk menciptakan dan menjalankan suatu organisasi yang leih berhasil. Six Sigma membutuhkan diversitas ketrampilan yang lebih besar, tidak hanya keahlian teknis.

d. Six Sigma mengakui baik perbaikan kecil ataupun perubahan besar, kedua-duanya merupakan bagian yang penting dari kelangsungan hidup dan keberhasilan bisnis.

e. Six Sigma tidak hanya berfungsi dalam proses jasa, tetapi juga menawarkan banyak peluang dalam manufakturing.

f. Perusahaan Six Sigma menetapkan standar persyaratan untuk pembelajaran, dengan dukungan investasi pada waktu dan uang untuk membantu karyawan memenuhi standar tersebut.

g. Six Sigma mencairkan rintangan organisasional. Disiplin dari pengelolaan proses adalah sangat penting dalam sistem Six Sigma sebagai cara untuk mengukur dan memperbaiki proses.

Six Sigma merupakan suatu sistem yang menyeluruh dan fleksibel untuk mencapai, mempertahankan, dan memaksimalkan keberhasilan perusahaan (Dlugacz, 2004: 2).

Dengan demikian, Six Sigma secara unik digerakkan oleh pemahaman yang dekat dengan kebutuhan pelanggan, penggunaan yang disiplin atas fakta, data, analisis statistikal, dan perhatian yang tekun dalam mengelola dan memperbaiki proses usaha.

A. MEMBANGUN MANAJEMEN MUTU PADA LEMBAGA PENDIDIKAN ISLAM
DI INDONESIA

Selama ini, mayoritas PTAI tidak memiliki lembaga atau unit penjaminan mutu karena dua alas an utama (Bunyamin \& Alamsyah, 2016: 207). Pertama, khusus bagi PTAIN sebagai lembaga yang selalu disubsidi pemerintah, selama ini merupakan "anak manja” yang keberadaannya terjamin APBN, bagaimanapun kualitasnya. Memang melalui BAN PT, pemerintah memiliki mekanisme tersendiri dalam menilai kualitas PTAI. Penilaian seperti ini bersifat top-down, global, tidak sinambung, dan hanya mengutamakan formalitas. Kedua, sebagai akibat dari alasan pertama, pada umumnya pimpinan PTAI melihat proses penjaminan mutu sebagai tugas manajemen dirinya (Musnandar, 2013: 58). Bila perkuliahan lancar, tidak ada gejolak di kalangan dosen, subsidi pemerintah berjalan terus, dan pimpinan terpilih kembali, maka mutu pendidikan dianggap baik (Maulida, 2018: 40). Ini semua sesungguhnya bukan indikator mutu, tetapi sekedar indikator manajemen PTAI yang belum tentu menjamin perbaikan kualitas pendidikan.

Akibat dari kedua hal di atas, penjaminan mutu hanya dianggap sebagai mekanisme inheren, sehingga pengawasan mutu dilakukan oleh pimpinan dari rektor sampai ketua jurusan maupun program studi. Dalam prakteknya mereka lebih berperan sebagai kelompok administrator eksekutif yang kurang memiliki kultur evaluative (Farhan, 2018: 88). Setahun sekali PTAI juga dimonitor tim inspektorat, namun monitoring ini lebih berfokus pada formalitas administratif bukan pada kualitas (Mochtar, 200I: 29) 
Penjaminan mutu berbeda dari mekanisme budaya monitoring tim inspektorat dalam beberapa aspek. Pertama, bottom-up bukan topdown, artinya penentuan kualitas yang hendak dicapai harus disesuaikan dengan kekuatan saat itu. Karena itu, berkaitan dengan hal ini budaya evaluasi diri menjadi niscaya. Lembaga penjaminan mutu akan selalu menyarankan untuk meningkatkan kualitas program studi atau fakultas yang ada daripada mengumbar nafsu membuka jurusan atau program studi dan fakultas baru.

Kedua, kolaboratif bukan instruktif. Semua pihak berjamaah dalam menentukan kualitas minimal dan prosedur kerja. Kesiapan jurusan A berbeda dengan $\mathrm{B}$, sehingga masing-masing memiliki pencapaian target yang berbeda, tetapi semuanya berkomitmen untuk meningkatkan kualitas dengan prosedur kerja yang relatif sama. Ketiga, lebih bersifat kualitatif daripada kuantitatif. Ini berarti bahwa keputusan itu diambil berdasarkan data-data kualitatif secara holistik. Kunjungan ke berbagai unit, wawancara dengan berbagai orang, dan pengumpulan dokumen sebagai bukti kegiatan atau portofolio harus dilakukan untuk menyepakati kualitas minimal dan standar operasional proses.

Keempat, berorientasi pada proses bukan hasil. Proses pendidikan yang berkualitas adalah kegiatan yang terorganisir demi tercapainya kualitas. Segala kegiatan harus tunduk dan taat pada kualitas sebagai "komando" tertinggi. Segala kegiatan dilembagakan dan tidak diserahkan kepada inisiatif dosen atau staf secara perorangan. Kelima, berbasis bukti bukan janji atau prestise (Wiwitan \& Yulianita, 2017: 7). Maka dari itu untuk menjaga kualitas, hasil yang akan dicapai dinyatakan dalam hasil (outcome). Sebagai contoh, indikator kualitas dosen perguruan tinggi $\mathrm{X}$ antara lain terbitnya sekitar 1000 judul publikasi setiap tahun. Bukti-bukti proses pendidikan yang berkualitas itu adalah dokumentasi. Tanpa dokumentasi tidak ada prestasi. Sering disebut bahwa untuk mengejar kualitas itu ada 3 (tiga) P, yaitu Paper, People, dan Process.

Berdasarkan uraian di atas, dapat digambarkan betapa beda antara penjaminan mutu dengan penilaian dari inspektorat. Karena itu, untuk memberikan inspirasi kepada para pengelola PTAI, marilah kita cermati beberapa kebijakan yang telah dikeluarkan Kementerian Riset dan DIKTI dalam penjaminan mutu bagi perguruan tinggi. Adapun penjaminan mutu perguruan tinggi merupakan konsep multi stakeholder yang mencakup (I) masyarakat luas, setempat, sekitar, nasional, dunia, (2) institusi pendidikan tinggi, dan (3) Direktorat Jenderal Pendidikan Tinggi. Jadi, sistem penjaminan perguruan tinggi dilakukan atas dasar penjaminan mutu internal, penjaminan mutu eksternal, dan perijinan penyelenggaraan program.

Penjaminan mutu internal merupakan penjaminan mutu yang dilakukan oleh institusi perguruan tinggi dengan cara yang ditetapkan perguruan tinggi yang bersangkutan (Kodrat, 2018: 2). Parameter dan metode mengukur hasil ditetapkan oleh perguruan tinggi sesuai dengan visi dan misinya. Dengan menjalankan penjaminan mutu internal, maka perguruan tinggi tersebut perlu melakukan evaluasi internal berupa evaluasi diri secara berkala. Evaluasi diri dimaksudkan untuk mengupayakan peningkatan kualitas berkelanjutan (Lubis \& Anggraeni, 2018: 135).

Penjaminan mutu eksternal merupakan penjaminan mutu yang dilakukan oleh badan akreditasi seperti BAN PT, ISO 900I:2000 atau lembaga lain dengan cara yang ditetapkan oleh lembaga akreditasi yang melakukan. Parameter 
dan metode mengukur hasil ditetapkan oleh lembaga akreditasi yang melakukan. Akreditasi oleh lembaga ini dimaksudkan guna melakukan evaluasi ekternal untuk menilai kelayakan program institusi pendidikan tinggi. Selain menilai kelayakan program, akreditasi juga dimaksudkan untuk pemberian saran peningkatan dalam mengupayakan peningkatan kualitas berkelanjutan (Warisno, 2018: I04).

Demikian pula dengan pengurusan perijinan penyelenggaraan program diberikan oleh Ditjen Dikti untuk satuan pendidikan yang memenuhi syarat penyelenggaraan program Pendidikan (Elbadiansyah, 2017: 49). Tata cara dan parameter yang digunakan ditetapkan oleh Ditjen Dikti. Perijinan selain dimaksudkan sebagai evaluasi eksternal juga untuk menilai kelayakan kepatuhan penyelenggaraan program. Dengan demikian, penjaminan mutu perguruan tinggi secara keseluruhan dimaksudkan untuk melakukan peningkatan kualitas institusi pendidikan tinggi secara berkelanjutan. Menurut Dikti, ada beberapa keuntungan perguruan tinggi melakukan penjaminan mutu, antara lain: (I) dapat memberikan pelayanan akademik terbaik bagi para mahasiswanya, (2) perguruan tinggi dapat mengelola program dan sumberdaya yang dimiliki secara optimal, (3) sebagai pertanggungjawaban perguruan tinggi kepada masyarakat, (4) melalui penjaminan mutu, peningkatan kualitas berkelanjutan akan lebih jelas, terarah dan mudah dilaksanakan, dan (5) perguruan tinggi mampu dan siap memasuki era kompetisi secara nasional dan global.

\section{B. PENUTUP}

Berdasarkan uraian di atas dan pengalaman pelaksanaan penjaminan mutu pada lembaga pendidikan Islam terutama Perguruan Tinggi Agama Islam (PTAI) selama lebih dari satu tahun, maka kegiatan penjaminan mutu di perguruan tinggi agama Islam dapat berjalan diperlukan beberapa syarat. Syarat-syarat tersebut di antaranya (I) komitmen dari seluruh pimpinan baik rektorat, dekan, ketua jurusan maupun program studi serta tim kantor penjaminan mutu yang ditunjuk. Tanpa adanya komitmen dari semua pihak tersebut, akan sulit terlaksana target dan kebijakan-kebijakan akademik yang telah digariskan, karena tidak mudah mengubah paradigma pimpinan dan seluruh sivitas akademika di kampus, (2) sikap mental para pimpinan di kampus, dari budaya ningrat menjadi budaya pekerja. Tidak mudah mencapai target yang ditetapkan dalam penjaminan mutu tanpa diikuti kerja keras dan tidak semua pimpinan mempunyai sikap mental mau bekerja keras. Tidak sedikit para pimpinan di PTAI yang hanya berharap mendapat uang banyak akan tetapi jarana yang mau kerja keras, (3) pengorganisasian. Sebagian besar PTAI tidak memasukkan Kantor Jaminan Mutu dalam statunya, sehingga tidak mudah membentuk unit atau lembaga ini dalam struktur organisasi dalam kampus. Perlu dilakukan langkah kreatif dan inovatif untuk menyiasati kondisi ini, sehingga anggaran pun dapat dipenuhi. Mengingat, anggaran ádalah masalah krusial yang sering menjadi masalah dalam kegiatan penjaminan mutu.

\section{DAFTAR PUSTAKA}

Asari, H. (1994). Menyingkap Keemasan Zaman Islam: Kajian atas Lembaga-Lembaga Pendidikan (Ist ed.). Bandung: Mizan.

Asikin, I. (2018). Implementasi Total Quality Management (TQM) di Pendidikan Tinggi. Hikmah: Jurnal Pendidikan Islam, 6(2), 318-334. 
Azizy, A. Q. (2003). Pengembangan IlmuIlmu Keislaman (Ist ed.). Jakarta: Direktorat Perguruan Tinggi Agama Islam Departemen Agama RI.

Azizy, A. Q. (2005). Pemikiran Islam Kontemporer di Indonesia (Ist ed.). Yogyakarta: Pustaka Pelajar.

Azizy, A. Q. (2007). Change Management dalam Reformasi Birokrasi (Ist ed.). Jakarta: Gramedia Pustaka Utama.

Azra,A. (2015). Genealogy of Indonesian Islamic Education: Roles in the Modernization of Muslim Society. Heritage of Nusantara: International Journal of Religious Literature and Heritage (e-Journal), 4(I), 85-II4.

Brue, G. (2005). Six Sigma for Managers (Ist ed.). Jakarta: PT. Media Global Edukasi.

Bunyamin, \& Alamsyah. (2016). Manajemen Mutu Perguruan Tinggi Agama Islam Swasta. Jurnal Pendidikan Islam, 28(2), 203-220.

Cudney, E. A., Venuthurumilli, S. S. J., Materla,T., \& Antony, J. (2018). Systematic Review of Lean and Six Sigma Approaches in Higher Education. Total Quality Management \& Business Excellence, I-I4.

Davis, M., \& Fifolt, M. (2018). Exploring Employee Perceptions of Six Sigma as a Change Management Program in Higher Education. Journal of Higher Education Policy and Management, 40(I), 8I-93.

Dlugacz, Y. D. (2004). Six Sigma Adds New Dimension to Quality Management Processes. Journal for Healthcare Quality,
$26(5), 2$

Elbadiansyah, D. (2017). Mutu Pendidikan pada Perguruan Tinggi Keagamaaan: Dari Manajemen Kelembagaan Hingga Konstruksi Kurikulum Interrelasi. Muaddib: Jurnal Studi Kependidikan dan Keislaman, 7(OI), 47-66.

Evans, J. R., \& Lindsay, W. M. (2007). An Introduction to Six Sigma and Process Improvement: Pengantar Six Sigma (Ist ed.). Jakarta: Thomson South-Western Salemba Empat.

Farhan, M. (20I8). Formulasi Kode Etik Pendidik dalam Perspektif Pendidikan Islam. Al-Fikri: Jurnal Studi Dan Penelitian Pendidikan Islam, I(I), 85-96.

Geneen, H. S. (2012). The Power of Six Sigma. In R. M. Penna \& K. Berger (Eds.), The Nonprofit Outcomes Toolbox (Ist ed., pp. 209-240). Hoboken, NJ, USA: John Wiley \& Sons, Inc.

George, M. L., Blackwell, D. K., \& Rajan, D. (2019). Lean Six Sigma in the Age of Artificial Intelligence: Harnessing the Power of the Fourth Industrial Revolution eBook: (M. L. George, Ed.) (Ist ed.). New York: McGraw-Hill Education.

Gupta, P. (20I5). Total Quality Management Using Lean Six Sigma. In A. Tarantino \& D. Cernauskas (Eds.), Risk Management in Finance (Ist ed., pp. 27-36). Hoboken, NJ, USA: John Wiley \& Sons, Inc.

Gupta, S. K., Antony, J., Lacher, F., \& Douglas, J. (2018). Lean Six Sigma for reducing student dropouts in higher education 
- an exploratory study. Total Quality Management \& Business Excellence, I-I6.

Harahap, S. (1998). Perguruan Tinggi Islam di era Globalisasi (Ist ed.). Yogyakarta: Tiara Wcana.

Kerzner, H. (2018). Project Management Best Practices: Achieving Global Excellence. (H. Kerzner, Ed.) (4th ed.). New York: Wiley.

Kodrat, D. (2018). Urgensi Perubahan Pola Pikir dalam Membangun Pendidikan Bermutu. Jurnal Kajian Peradaban Islam, 2(I), I-6.

Laureani, A., \& Antony, J. (2018). Leadership: A Critical Success Factor for the Effective Implementation of Lean Six Sigma. Total Quality Management \& Business Excellence, 29(5-6), 502-523.

Lubis, Z., \& Anggraeni, D. (2018). Paradigma Pendidikan Agama Islam di Era Globalisasi Menuju Pendidik Profesional. Jurnal Studi Al-Qur'an, I5(I), I33-I53.

Maulida, A. (2018). Kompetensi Pendidik dalam Perspektif Mohammad Natsir (Studi Analitis Pemikiran Pendidikan M. Natsir dalam "Fiqhud Dakwah"). Al-Fikri: Jurnal Studi Dan Penelitian Pendidikan Islam, I(2), 39-46.

McMunigal, J. E., \& Barry Bebb, H. (2015). Design for Six Sigma: A Mandate for Competitiveness. In M. Kutz (Ed.), Mechanical Engineers' Handbook (Ist ed., pp. I-30). Hoboken, NJ, USA: John Wiley \& Sons, Inc.

Mochtar, A. (200I). Membedah Diskursus
Pendidikan Islam (Ist ed.). Yogyakarta: Kalimah.

Montgomery, D. (2017). Lean Six Sigma in Higher Education. Quality and Reliability Engineering International, 33(5), 935936.

Musnandar, A. (2013). Implementasi Manajemen Strategi dalam Pengembangan Budaya Organisasi pada Perguruan Tinggi Islam Studi Kasus di UIN Maliki Malang. Ulul Albab: Jurnal Studi Islam, I4(I), 57-83.

Pande, P., \& Holpp, L. (2005). What is Six Sigma: Berpikir Cepat Six Sigma (2nd ed.). Yogyakarta: Andi.

Pande, P. S., Neuman, R. P., \& Cavanagh, R. (2014). The Six Sigma Way: How to Maximize the Impact of Your Change and Improvement Efforts, Second edition eBook: (2nd ed.). New York: McGrawHill Education.

Pyzdek, T., \& Keller, P. A. (2018). The Six Sigma Handbook (5th ed.). New York: McGrawHill Education.

Syamsuddin, Samrin, S., \& Alim, N. (2018). Manajemen Strategi dalam Penguatan Program Studi Manajemen Pendidikan Islam (MPI) Fakultas Tarbiyah dan Ilmu Keguruan IAIN Kendari. Al-Ta'dib: Jurnal Kajian Ilmu Kependidikan, I I(2), I9-36.

Tompkins, J. (2005). Organization Theory and Public Management. Wadsworth, Cengage Learning.

UNESCO. (I998). World Declaration on Higher Education for the Twenty- 
First Century: Vision and Action Main provisions relating to right to education. New York.

Warisno, A. (2018). Pengembangan Sumber Daya Manusia dalam Peningkatan Mutu Lulusan pada Lembaga Pendidikan Islam di Kabupaten. Ri'ayah: Journal of Social and Religious, 3(02), 99-II3.

Wiwitan, T., \& Yulianita, N. (2017). Strategi Marketing Public Relations Perguruan Tinggi Islam Swasta: Peluang dan Tantangan di Era MEA. MediaTor: Jurnal Komunikasi, IO(I), I-IO.

Zuckweiler, K. M. (20I I). Teaching Six Sigma to Undergrads: A Simplified Real Project Approach. Decision Sciences Journal of Innovative Education, 9(I), I37-I42. 